Management international

International Management

Gestiòn Internacional

Addressing Identity Tensions Through Paradoxical Thinking:

Lessons from Artistic Interventions in Organizations

Une approche des tensions identitaires par la pensée

paradoxale : le cas des interventions artistiques en entreprise

Considerando las tensiones de identidad mediante el

pensamiento paradójico: lecciones aprendidas de las

intervenciones artísticas en organizaciones

Ariane Berthoin Antal, Gervaise Debucquet et Sandrine Fremeaux

Volume 21, numéro 1, automne 2016

URI : https://id.erudit.org/iderudit/1052495ar

DOI : https://doi.org/10.7202/1052495ar

Aller au sommaire du numéro

Éditeur(s)

HEC Montréal

Université Paris Dauphine

ISSN

1206-1697 (imprimé)

1918-9222 (numérique)

Découvrir la revue

Citer cet article

Berthoin Antal, A., Debucquet, G. \& Fremeaux, S. (2016). Addressing Identity Tensions Through Paradoxical Thinking: Lessons from Artistic Interventions in Organizations. Management international / International Management / Gestiòn Internacional, 21(1), 25-40. https://doi.org/10.7202/1052495ar
Résumé de l'article

Dans le monde professionnel caractérisé par des logiques multiples allant de la conformité à l'innovation, beaucoup d'employés éprouvent des tensions entre identité professionnelle et identité artistique. L'article mobilise des données issues d'un questionnaire en ligne auprès d'employés, managers, et artistes dans 86 entreprises espagnoles, et revisite les tensions identitaires à l'aune de la pensée paradoxale. Les résultats montrent que la participation à une intervention artistique permet de mieux appréhender au quotidien les tensions identitaires entre soi et les autres, entre conformité et créativité, et de les dépasser pour renouveler les modes de collaboration, idées et méthodes de travail.
Tous droits réservés ㄷ Management international / International Management / Gestión Internacional, 2016
Ce document est protégé par la loi sur le droit d'auteur. L’utilisation des services d'Érudit (y compris la reproduction) est assujettie à sa politique d'utilisation que vous pouvez consulter en ligne.

https://apropos.erudit.org/fr/usagers/politique-dutilisation/ 


\section{Addressing Identity Tensions Through Paradoxical Thinking: Lessons from Artistic Interventions in Organizations ${ }^{1}$}

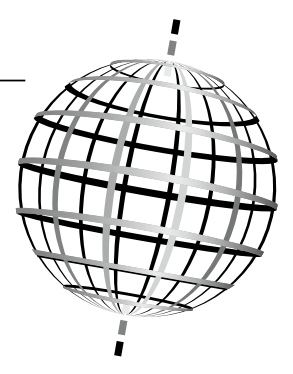

\section{Une approche des tensions identitaires par la pensée paradoxale : Le cas des interventions artistiques en entreprise}

\section{Considerando las tensiones de identidad mediante el pensamiento paradójico: lecciones aprendidas de las intervenciones artísticas en organizaciones}

\author{
ARIANE BERTHOIN ANTAL \\ Research Group "Science Policy Studies", \\ WZB Berlin Social Science Center
}

\author{
GERVAISE DEBUCQUET \\ Audencia Nantes. Business School
}

\author{
SANDRINE FREMEAUX \\ Audencia Nantes. Business School
}

\section{ABSTRACT}

In organizational contexts characterized by multiple logics spanning from conformity to innovation, many employees experience tensions between a business-like identity and an artistic identity. The contribution uses data generated from Web-based surveys of employees, managers, and artists in 86 Spanish companies to explore how identity tensions can be addressed with paradoxical thinking. It shows that engaging in artistic interventions can help people accept and deal with identity tensions between selfand-other and between conformity-creativity in the workplace, enabling the removal of real or subjective barriers to generating new ways of collaborating, new ideas and new ways of doing things.

Keywords: Artistic interventions, identity development, identity tensions, paradoxical thinking, conformity, creativity

\section{RÉSUMÉ}

Dans le monde professionnel caractérisé par des logiques multiples allant de la conformité à l'innovation, beaucoup d'employés éprouvent des tensions entre identité professionnelle et identité artistique. L'article mobilise des données issues d'un questionnaire en ligne auprès d'employés, managers, et artistes dans 86 entreprises espagnoles, et revisite les tensions identitaires à l'aune de la pensée paradoxale. Les résultats montrent que la participation à une intervention artistique permet de mieux appréhender au quotidien les tensions identitaires entre soi et les autres, entre conformité et créativité, et de les dépasser pour renouveler les modes de collaboration, idées et méthodes de travail. Mots clés : Interventions artistiques, développement identitaire, tensions identitaires, pensée paradoxale, conformité, créativité

\section{RESUMEN}

En organizaciones caracterizadas por lógicas que van desde la conformidad hasta la innovación, muchos empleados experimentan tensiones entre una identidad empresarial y una artística. La contribución utiliza los datos de encuestas Web realizadas a los empleados, directivos y artistas de 86 empresas españolas, y explora cómo las tensiones de identidad pueden dirigirse con el pensamiento paradójico. El análisis muestra que la participación en intervenciones artísticas ayuda a que las personas se ocupen de esas tensiones identitarias, $y$ entre conformidad vs creatividad en el lugar de trabajo, permitiendo de superarlas para la generación de nuevas ideas y formas de colaborar.

Palabras clave: Intervenciones artísticas, desarrollo de la identidad, tensiones de identidad, pensamiento paradójico, conformidad, creatividad

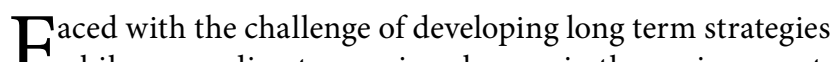
while responding to ongoing changes in the environment, managers and employees must always contend with multiple logics characterized by conformity and creativity as well as stability and change (Gulati, Sytch \& Tatarynowicz, 2012). Creativity is present in all fields of human activity, and the demands of stability and conformity cannot eliminate it. As
Simonton (2000) pointed out, the demand for activating creativity is increasingly based on the belief that "organizations and even economic regions that embrace creativity generate significantly higher revenue and provide greater stability into the future as well" (van der Pol, 2011, p. 1). Studies have shown that logics in organizations may shape "individuals' practices, their interests as well as their identities" (Pache \& Santos, 2013, p. 6), in other

1. Acknowledgements:

We are grateful to Conexiones Improbables for providing research access to the cases, to the artists, managers and employees who responded to our surveys, to Ilana Nussbaum Bitran at the WZB Berlin Social Science Center for her help in preparing the data analysis, and to the Advanced Study Center Konstanz for its support in the early phase of the project. Many thanks also to our careful reviewers whose questions and suggestions prompted us to clarify our ideas and strengthen our argument. 
words their response to the identity-defining question "who am I?" (Kenny, Whittle \& Willmott, 2011, p. 180). Not surprisingly, there is "increasing acceptance of identities as sites of tension" (Meisenbach, 2008, p. 259).

Paradox results when logics are rooted in opposing concepts (Poole \& Van de Ven, 1989). Paradoxes may appear to inhibit activity and innovation, but they may also enhance performance if they are considered as a necessary whole rather than as separate elements having different degrees of value. Paradoxical thinking offers precisely this holistic perspective, because it accepts the complexity of these elements in tension with one another (Smith \& Lewis, 2011, p. 382; Hahn, Preuss, Pinkse \& Figge, 2014; see also Cameron \& Quinn, 1988; Poole $\&$ Van de Ven, 1989). The ability to handle multiple logics with paradoxical thinking appears particularly significant in light of research indicating that individuals engaging with multiple logics are likely to contribute to institutional adaptation and change (Pache \& Santos, 2013, p. 28).

As White (1992, p.4) noted, identity tensions are intensified in contexts characterized by change and uncertainty. Gotsi, Andriopoulos, Lewis, Ingram and Amy (2010) showed that creative workers experience tensions between two identities, namely artistic identity and business-like identity. Creative workers develop an artistic identity in the sense that they see themselves as distinctive in their passion, self-expression and creativity, but they also need to develop a business-like identity to feel effective in achieving organizational objectives. The experience of this identity tension is not limited to the creative industries, because organizational scholars like Nancy Adler $(2011,2015)$ and Ed Schein (2001) stress that people in forprofit companies (and other kinds of organizations) also need to develop their artistic identity, allowing them to express themselves, pursue their passion, and exercise their creativity in defining and achieving their business objectives (see also Meisiek \& Hatch, 2008).

The fact that managers in an increasing number of non-arts based organizations in the private and public sector have been bringing in artists responds to the dual demand for new sources of innovation and for new approaches to humanly meaningful workplaces (Darsø, 2004, 2016). These artistic interventions are a kind of intercultural interaction whereby "people, practices, or products from the world of the arts enter organizations" (Berthoin Antal, 2014, p. 177), offering employees opportunities to explore new ideas and experiment with different ways of thinking, doing, and being at work. Managers bring artists in to work with employees for many different reasons, such as to develop skills (e.g., creativity, leadership, communication), stimulate the development of new products and services, reconsider their relations with their environment, or think about their organizational model (Berthoin Antal, 2014). They expect that the interaction will be generative because they see artists as bearers of creative ways of doing things, and the different practices and norms they embody as likely to spark off fresh responses from employees (Barry \& Meisiek, 2010; Schein, 2001).

We have been studying this phenomenon in different countries for some years with a wide-open lens, seeking to understand the process and its effects from the perspective of the participating employees, artists, and the managers who commission them (project owners). In this article we explore our data from 86 organizations in Spain in order to clarify whether and how artistic interventions may serve as opportunities for people engaging in diverse organizational settings outside the art world (a) to become aware of identity tensions that can surface in various professional situations and (b) to accept the tensions through paradoxical thinking.

The first section of this article provides the analytical framework by summarizing research on identity tensions and paradoxical thinking and relating them to literature on artistic interventions. The second section describes how we collected the data and conducted the analysis. In the third section, we present our findings, enriching theory-building on identity as a multifaceted construct that can also encompass tensions between apparently contradictory identities at work. We draw on our data to illustrate several kinds of identity tensions that artistic interventions bring to the surface, and to show how the participants deal with them by engaging in paradoxical thinking. In conclusion, we consider the implications for management and for future research.

\section{Framing the study}

\section{Artistic Interventions in Organizations as Spaces FOR IDENTITY TENSIONS}

Studies on organizational identities and identities at work address the way people define themselves through the work they perform and the organizations with which they associate. Kenny et al. (2011) recognize that identities at work depend on and are linked to many other areas of people's lives; and that the different aspects of identity are not always coherent and can be competing. For these two reasons, mingling different areas of life in the working environment will necessarily have an impact on identity development and will heighten tensions between different aspects of identity, especially when stability and conformity confront change and creativity in a given context. Such effects are to be expected in artistic interventions that involve bringing the values and practices from the world of the arts into non-arts based organizations. During these essentially intercultural interactions participants may become particularly aware of distinctive aspects of their identity (Lee, 2006; Sussman, 2000). Such an experience may also stimulate them to choose to adjust their identity to include characteristics they discover in the interaction with the other culture (Garcia \& Hardy, 2007, p. 366; Maguire \& Hardy, 2005, p. 35; see also Adler, 2002).

Artistic interventions are intercultural encounters because, as Dewey pointed out, "to multitudes art seems to be an importation into experience from a foreign country" (Dewey, 1934/2005, p. 11). Other scholars speak of artistic interventions as crossing the "cultural divide" (Strauß, 2009). The interaction at work between employees and artists may therefore have consequences for identity development at the individual as well as the collective level (Hatch \& Schultz, 1997). Meisiek and Hatch argue that "artistic processes allow organizational members to playfully explore cultural self-understanding and stakeholder images of the organization, which in turn lead to identity change" (2008, p. $420)$. We therefore propose to explore how artistic interventions 
can open spaces for experiencing heightened identity tensions that are likely to fuel identity development.

Indeed, when artists are invited into organizations, even for a short time, they inevitably apply their culturally-formed identity filters to observe and engage with individuals and to make sense of the organization's practices. In turn, the members of the organization embark on the interaction with their own frames of reference to observe and engage with the artists' ways of doing and being in their environment. During the intervention the participants in the intercultural encounter may experience resonances between their worlds and also challenges to their views and norms. Independently of the purpose of the artistic interventions and the art-based methods used in the process, the interaction between artists and members of the organization is therefore always intrinsically a meeting of identities rooted in different worlds. This intercultural encounter is likely to generate identity tensions when employees compare and contrast the identity of the artist with the characteristic features of their own identity.

\section{IDENTITY TENSIONS AT WORK}

Previous research has found that employees experience identity tensions at work. For example, Westenholz (1993, p. 42-45) observed three apparently contradictory frames of reference with which employees were identifying in a producer's cooperative, leading them to experience tensions between being members of a "democracy," a "wage-earner system," and a "firm". Another example is the study in five product design companies (Gotsi et al., 2010) which found that employees were dealing on a day to day basis with multiple identity demands. They experienced identity tensions between the desire for creativity, self-expression and innovation on the one hand, and the desire to achieve objectives in the context of organizational and economic constraints (such as budgets, deadlines, market demands, client satisfaction), on the other. The studies show that the tensions are inherently present in each individual, rather than being oppositionally distributed across different people and tasks in the organization. In the product design firms the identity tensions became particularly strong when work required creativity (Gotsi et al., 2010, p. 782). Given the increased demand for creativity and innovation in all kinds of organizations, we expect that the tension between aspects of employees' "artistic identity" (such as the desire for creativity) and what Gotsi et al. (2010) refer to as their "business-like identity" (such as aspiring to meet client needs) will be heightened in artistic interventions. In both of the studies cited above the authors found that paradoxical thinking proved helpful in dealing with identity tensions, therefore, we consider it worth examining its potential in the context of experiencing artistic interventions. The theoretical value of such an examination lies in enriching conceptualizations of identity tensions at work and clarifying the dimensions and dynamics of handling them. For organizational practice, insights from identifying and analyzing these processes can provide orientation for supporting meaningful and generative individual and collective processes of identity development, especially in complex contexts in which innovation is prized.

\section{Paradoxical Thinking in Response to Identity Tensions}

As Putnam recently pointed out, the past 25 years have witnessed an exponential growth in attention to the study of tensions and paradoxical thinking in the organizational landscape (2015, p. 1), because "organizational actors have to make choices, move forward, respond to, cope, or manage paradoxical tensions, not just as an anomaly, but as a routine endeavor in organizational life" (2015, p. 2). Such conditions place high demands on the cognitive capacities of managers and employees in organizations. Hahn et al. (2014) distinguish between two ideal-types of cognitive framing to address complex situations, which they call the "business case frame" and the "paradoxical frame." They show how each implies a very different approach to dealing with tensions. Whereas the former frame seeks to eliminate tensions, the latter is oriented to accepting them.

The business case frame is founded on a "belief in a unitary truth [which] means inconsistencies cannot fundamentally coexist" (Smith \& Tushman, 2005, p. 525). Applying this frame entails establishing a linear logic to align the various dimensions of a situation in an order that reconciles or excludes inconsistencies. The business case frame has an "unequivocal focus on economic attributes," so other attributes of a complex situation are either aligned behind economic ones, or treated as irrelevant, in order to reduce ambiguity and remove tensions.

By contrast, the paradoxical frame seeks to accept the inevitability of tensions between co-existing dimensions because paradoxes are "contradictory yet interrelated elements that exist simultaneously and persist over time" (Smith \& Lewis, 2011, p. 382; see also Cameron \& Quinn, 1988; Poole \& Van de Ven, 1989). Applying this frame leads actors to recognize the tensions and "to learn to live with" (Lewis, 2000, p. 764) and "work through" paradox (Lüscher \& Lewis 2008, p. 227). Paradoxical thinking is rooted in "a logic of difference" that calls for breaking out of the linear rationality of "either-or" thinking, to find "both-and" and "more than" ways of addressing complexity (Putnam, 2015, p. 3).

Paradoxical thinking offers a positive approach to dealing with, or, as Gotsi et al. (2010, p. 782) write, "regulating"2 the identity tensions that arise from the contradictions inherent in organizations. The process, which is both personal and collective (Gotsi et al., 2010, p. 785), entails both differentiation in which the participants become aware of the disparate elements that underlie conflicting identities, and integration to achieve a synergy between them. In order for synergy to be attained, individuals must be aware of the need to preserve each of their identities. In other words, integration is not conceivable

2. We do not follow Gotsi et al. (2010) in using the term identity regulation because, as they recognize, it is often "associated with management's strategy aimed at influencing identity work in directions that support organizational goals" (p. 784). The authors try to disentangle their use of the term from this discourse (p. 784-785), but we share the concern of authors who critically highlight potentially oppressive effects of managerial regulation of identity (Alvesson \& Willmott, 2002; Kunda, 1992) so we prefer to avoid the confusion by avoiding the term, although in the French literature (e.g., Reynaud, 1997) the term is not laden in the same way. 
without differentiation. Whereas for the business case frame, the strong focus on economic aspects results in low degrees of differentiation and integration; the paradoxical frame helps to address the complexity that is inherent in most organizations today. Indeed, by accepting the tensions, paradoxical thinking permits people to handle a larger number of cognitive elements as well as a multitude of connections without having to establish a hierarchy among them (as the business-case approach would require, Hahn et al., 2014, p. 466). According to Gotsi et al. (2010), differentiation helps workers to switch between different roles at different points in time, whereas integration helps them to embrace disparate roles as synergistic.

Numerous identity tensions can be addressed by paradoxical thinking: collaboration-control, individual-collective, flexibility-efficiency, profit-social responsibility (Smith \& Lewis, 2011). However, the literature on paradoxical thinking points in particular to two categories of identity tension: the tension between action for oneself and action for others, and the tension between stability/conformity and change/creativity (Poole \& Van de Ven, 1989, p. 571; Smith \& Lewis, 2011, p. 393; Zhang, Waldman, Han \& Li, 2015, p. 541). Lips-Wiersma and Wright (2012) also discuss these two tensions, which they see as the core of a comprehensive measure of meaningful work. According to these scholars, the "self versus others" tension refers to the ongoing challenge of meeting the needs of the self, while also meeting the needs of others (Lips-Wiersma \& Wright 2012, p. 660). The "being versus doing" tension relates to an attitude of taking one's time to examine a situation before undertaking a change, on the one hand, and an attitude focusing out into the world, on the other (Lips-Wiersma \& Wright 2012, pp. 660-61).

The tension between self and other has been addressed by scholars under other headings, such as individuality and collaboration, ingroup and outgroup (Smith \& Lewis 2011, p. 385). Zhang, Waldman, Han and Li (2015, p. 541) recently extended the reach of this stream of research into Asian contexts, and call this tension "self-centeredness and other-centeredness". Smith and Lewis (2011) also discuss extensively the paradoxical tension between creativity and conformity, as do Clegg, Vieira da Cunha and Pina e Cunha (2002): "All organization is founded on paradox: on the one hand it contains free, creative, independent human subjects; on the other hand the relation between these subjects aspires to be one of organization, order and control" (Clegg et al. 2002, p. 483). Zhang et al. (2015, p. 541) identify several forms that this tension takes in organizations, namely requiring managers to treat "employees uniformly, while allowing individualization; enforcing work requirements, while allowing flexibility; and maintaining decision control, while allowing autonomy."

The analytical framework generated through this review of the literature on identity tensions and paradoxical thinking enables us to examine responses to situations in organizations that are likely to bring tensions between elements of the "business-like identity" and the "artistic identity" to the surface, namely artistic interventions. Which aspects of identity tensions suggested in the literature emerge in these interactions? Is there evidence of paradoxical thinking to indicate that the experience in artistic interventions can help people accept and handle these identity tensions in daily work situations? Answering these questions with our data will contribute to a better understanding of the nature of identity tensions in contexts requiring multiple logics, and of the contribution artistic interventions can make to exercising paradoxical thinking.

\section{Methodology}

\section{Data Collection: The Empirical Material}

The data for our study was generated through Web-based surveys of participants in artistic interventions produced by the Spanish intermediary organization 'Conexiones Improbables' in the Basque country and Catalonia (Berthoin Antal \& Nussbaum Bitran, 2015). The data collection process started in 2011 and continued to the point of saturation in December 2014, when we found that the additional information was becoming redundant (Gioa, Corley \& Hamilton, 2013).

These interventions last between 4 and 9 months, during which time the artists meet with the company participants several times to work on an issue the project owner identifies in advance. The project owners are senior managers or, in very small companies, the owner himself/herself. In the cases under study most of the project owners participated in the project alongside their employees. As Conexiones Improbables announces on its website (www.conexionesimprobables.es/), the objective of participating in artistic interventions is to "interact in search of committed social and productive innovation" in a process intended to generate mutual benefit for the artists and the members of the organization. The project owners who brought in the artists in the cases we studied wanted to address challenges such as developing new ways of engaging with their environment, improving communication internally or externally, developing ideas for new products or services.

During the interventions the artists invite the participants to work and play with different art-based methods to visualize ideas and express thoughts and feelings. In the 9-month long projects the artists engage with the organization as many times as they agree with the project owners and participants. In the short projects, which Conexiones Improbables calls "Creative Pills", they meet 3-4 times over the 4-month period. For both kinds of projects Conexiones Improbables organizes an introductory session for all the organizations and artists participating in a cohort, and another at the end of the period to share their results and learn from each other's experiences.

Almost all the organizations in the sample are small and medium-sized organizations, operating in diverse sectors such as retail, public administration, education and health, manufacturing (for details on the composition of sample, see Berthoin Antal \& Nussbaum Bitran, 2015, p. 22-32). Most of them have fewer than 5 employees and some are run by an entrepreneur without any full-time employees. This study encompasses a total of 84 artistic interventions, which involved 86 organizations ${ }^{3}, 24$ solo artists and 24 artists' collectives.

3. In two cases, two companies participated together, hence 84 artistic interventions and 86 companies. 
We chose a qualitative approach to studying the experience of participating in artistic interventions for several reasons. Although the phenomenon has grown over the past decade, and the number of publications has increased, in-depth research on artistic interventions is still quite new. We wanted to use a method that would permit participants to express themselves freely in their own words. We designed pre- and post-experience questionnaires with a mix of open and closed questions for the artists, employees and the project owners (managers) responsible for the artistic intervention who participated in three different rounds of projects. The questionnaires elicited the thoughts, feelings and observations of the three types of participants before the artistic interventions, and then their reflections on the experience several weeks after the interventions.

\section{Data Analysis}

For this article we selected the open questions in our survey which generated responses that offered insights into identity tensions (see Table A1 in the appendix for the selected questions). The majority of respondents formulated their responses in Spanish (which two of the authors understand); we obtained translations of the Basque responses (which none of the authors speak) into Spanish.

Our analysis is based on 171 responses from artists (88 to pre-experience questions, 83 to post-experience); 178 employee responses (110 pre-, 68 post-experience); and 132 responses from the managers who commissioned the project (referred to as project owners, 73 pre-, 59 post-experience). Given the small size of the majority of organizations, the project owners participated in the projects, either alone or alongside their employees, so in effect the data base encompasses 310 responses from members of the organizations. We include the identity issues that the artists raise in their responses because the dynamic that the artistic intervention puts in motion affects the identity tensions they experience too.

We undertook a "structured ordering" of the qualitative data (Clarke, Brown \& Hailey, 2009, p. 331). The analysis first focused on identifying patterns and variance expressions relating to identity in the responses from the three groups, to see whether there were a) expressions of identity tensions, and b) evidence of how the participants dealt with those tensions. It would not have been effective to ask the respondents directly about tensions they experienced and of course they did not always explicitly formulate their experiences in terms of tensions. It was noteworthy that the artists showed a striking ability to put into words the mechanisms that led to identity tensions; they addressed these issues more directly than the other groups of respondents. Our analytical process therefore entailed drawing out the implicit tensions suggested in the qualitative data, using the lexical and syntactic occurrences as evidence. We conducted our analysis first within each group of respondents (artists, employees, project owners), then sought similarities and differences between them to identify common themes. This enabled us in the next step to connect the themes that emerged from our data with the overarching themes relating to identity tensions derived from our literature review.
In order to maximize the objectivity of the step of categorization, all three authors discussed the outcome. This approach permitted us to follow the recommendations for a systematic qualitative data analysis (Miles \& Huberman 1994, p. 56) to identify the recurring ideas in the responses. Thirdly, we took advantage of the diachronic research design with which we had generated pre- and post-experience responses in order to trace how the participants imagined the encounter with "the other" would be before the artistic intervention, and the actual value that the participants generated together during the experience.

\section{Results}

The data analysis reveals that the three kinds of participants became aware of the tensions between business-like identity and artistic identity, and it shows that they share a willingness to accept and deal with these tensions. The data also indicates that artistic interventions stimulate a tension between self and other: there is both a certain amount of apprehension about engaging with the unknown other and the expectation that the self will benefit from engaging with the other's perspective. These findings show that artistic interventions can facilitate synergies between action for oneself and action for and with the other. The data also reveal tensions between conformity and creativity: expressions of concern that the demands of creativity and those of daily work may conflict, then the discovery of the benefits creativity can bring to the workplace, including the development of perspectives and practices. These responses to the experience suggest that artistic interventions are opportunities to create synergies between conformity and creativity that are a resource for identity development as well as for innovation.

We present the results of our findings on identity tensions and the dynamics of handling them with paradoxical thinking and illustrate them with quotations from our respondents in two ways: in the text that follows and in three tables (see Tables A2, A3 and A4 in the appendix). Each table brings together the three themes for a group of participants, namely a) openness to accept the tensions; b) tensions between self and other; c) tensions between conformity and creativity, and provides the most significant quotations from our data to illustrate them. The examples of pre- and post-experience responses are placed in separate columns in order to highlight the process of becoming aware of identity tensions. Table A2 presents selected quotations from the artists, Table A3 from the employees, and Table A4 from the project owners. These tables complement the material from the responses that we have integrated into the text.

We start with the findings for the artists because their responses illustrate a high level of reflexivity about the experience. Their engagement in the artistic intervention affects their own identity tensions while also bringing to the surface inherent identity tensions in the organization. The artists' reflections also offer a kind of backdrop for understanding the responses of the other two groups. The employees express their hopes, thoughts and feelings about the experience. The project owners' responses are formulated, as we requested, from a managerial perspective rather than a reflection on their personal experience. 


\section{Points of Departure: Openness to Accepting Tensions}

Our qualitative reading of the pre-experience questionnaires indicated that members of all three groups are open to experiencing potential tensions. These tensions emerge from the differences they expect between the identities they associate with the world of organizations and the world of the arts. The oppositions between dimensions they mention show that they envisage artistic interventions as embarking on crossing the "cultural divide" between the world of the arts and the world of organizations (Strauß, 2009).

We asked the participants about their hopes and any concerns they might have before the experience. The combination of questions was designed to elicit implicit images of "the other" and expectations that the unusual encounter with "the other" might entail. Many respondents said they had "no concerns" but those who did formulate some concerns indicate the awareness of the tension between the "business-like identity" that dominates the organizational setting and usually leaves little space for the "artistic identity." The two primary concerns the artists express are about their "usefulness" in the eyes of the world of organizations and "unrealistic expectations" they might face in the organization. For their part, some employees and project owners are anxious about the difficulties to "find a way to channel the ideas of the artists and make them viable." They also mention concerns about finding the time for the project while still meeting their work targets. Overall, however, the participants in all three groups seem confident that the upcoming experience would be a positive one.

The artists (Table A2) sense from the outset that the conditions for a positive experience will need to be co-constructed as a process. The conditions revolve around developing a "common language" and finding ways of "playing together."

"[hope] that they understand my language, and I theirs. That we work together to establish a minimum of rules of the game in order to be able to activate these games of roles, of imaginary descriptions, of self-interviews, of possible futures...." (PRE ${ }^{4}$-Artists)

"Listening is also a good mechanism to become conscious in the interaction. To be open, observe, ask and listen. It is about expressing and absorbing, dilating and contracting, giving and receiving." (PRE-Artists)

Members of the organization (Tables A3 and A4) are also aware of the need to engage in a spirit of openness as a crucial precondition to get something the most out of the unusual encounter. They recognize that there are different interest groups involved and they aspire to develop new, mutually beneficial outcomes. The language they choose suggests they are drawing on both the business-like identity and the artist identity.

"We cannot waste this tremendous opportunity. We have to succeed in creating an excellent connection, communication and 'feeling' with the artist so that together we can all benefit from the project of connections to achieve unexpected results, disruptive, new and useful for ourselves, for the artists, the company, and the region." (PRE-employees)
The responses to the post-experience questionnaires show that almost all the participants found the experience of the artistic intervention "stimulating", "useful", and "inspiring." They became aware of their ability to open themselves up to the difference and permit the distance between the world of the arts and the world of organizations/business to be bridged. They do not pretend that the process was easy; even with the best intentions, opening up to the other in the workplace setting does not come naturally! Participants write about the effort it took to achieve the quality of engagement that they hoped for (Tables A3 and A4).

"We lacked a bit of symbiosis between artist and employees. Both partners had to adapt to the working modes of the other." (POST-employees)

The artists also recognize that achieving the conditions for openness to other ways of seeing and doing things requires effort from all the participants (Table A2). They mention the important role played by the intermediary organization (Conexiones Improbables) that brings the artists into the organizations in laying the groundwork for framing the encounter and for addressing potential tensions that could arise in the interactions.

"[For] the initial dynamic, very important for companies or organizations. I suggest a more personal participation and a more profound rupturing of schemata and protocols. Conexiones Improbables could definitely construct an even clearer definition of the scenario for the development of projects common to both parties. The presentation and acceptance of a broad white canvas for the artists when you enter into the organization to participate there is vital for a good start of the project." (POST-Artists)

This recommendation by a project owner for ways of improving the framing of an artistic intervention is probably relevant beyond this specific context: a clearly defined framework for reflection is important for other moments of working through identity tensions in the workplace as well. Other insights into how to create the spirit of openness for engaging with difference also emerged from the post-experience reflections. Participants reporting having tried out new ways of opening up that would be relevant for other new situations and projects (Tables A3 and A4).

"The impact is related to the importance of starting from a stance of listening which permits you to take into account the rhythm, sensitivity and creative state of the person or organization with which we are going to work so that a fluid relationship is established and can navigate through transformative moments without fear or blockages, with confidence and respect. We do not impose a creative and artistic rhythm but we boost the creativity, and at the same time we are drawing our creative capacity from what is predictable from its own process" (POST-Project owner).

Applying such a stance beyond artistic interventions would contribute to removing certain fears or blockages that are often observed in dealing with new situations.

The artistic intervention appears to be an experience of opening to difference that enabled the participants to dare to

4. We refer to responses from the pre-experience surveys as PRE, and to the post-experience surveys as POST. 
address identity tensions without knowing where the process would lead them. This opening up permits the discovery of potential synergies between the business-like and artistic identities that the artistic interventions stirred up or revealed. In the next step we discuss the tensions between self and other, and between creativity and conformity for which we found evidence in the data.

\section{Tension SelF-other}

The data from the pre- and post-experience responses reveals that the identity tension of self-centeredness/other-centeredness is relevant for all three groups of participants. The artists are more explicit than the others in putting into words the diverse tensions and the benefits they expect to draw from the confrontation both at the professional and personal level (Table A2).

"I am really interested in working with communication and with rural organizations from a distributed perspective. By hybridizing contexts we can contaminate them and take paths we would never have considered beforehand." (PRE-Artists)

"The most rewarding thing is that it permits you to be another person and live in spaces with other rules. When you play at being another you become aware of many things about this character and about yourself. It is an exploration into the interior." (PRE-Artists)

They clearly want to experiment with the differences and the tensions.

"It is about making a bridge between two worlds, between two different points of views and in some cases between antagonistic ones." (PRE-Artists)

The participants inside the firm expect that the artists will help them improve the relationship and communication with colleagues, a better understanding of the "others" in the organization and with whom they share a certain number of values (Tables A3 and A4). Most of the respondents expect a good outcome, even if they cannot always define it at the outset. They write that the experience will "have a positive effect" for them and for the others because they "will always be able to learn something" about themselves, their colleagues or their clients.

"In my opinion, although we have different kinds of work, a close relationship can exist, since we all work with clients. Sometimes we focus only on a few aspects and it would be interesting to complement that with an external view." (PRE-Employees)

The discovery of the "other" is multifaceted. The respondents refer to getting to know their colleagues better or to discovering the needs of clients, colleagues, or the work group more clearly. The other is also the artist who is considered as a neutral facilitator of change. The presence of a third party, foreign to the organization, invites participants to explore an external perspective on organizational interactions rather than being limited to their normal internal way of seeing things. They refer to "the view from other eyes", "from outside", "looking at us from a different perspective", "the need to think outside the box".

"The artists help employees to see the same projects in a new way, 'from out of the box' [English original]." (POST-project owners)
“[...] Because artists never stop surprising you with their different way of seeing reality.” (POST-project owners)

As a project owner explained, he would like the encounter and the mirroring effect to have an impact at the individual level by enabling

"A transfer of knowledge between the two parties. So that employees in future can leave their comfort zone and think more in terms of innovation." (PRE-project owners)

This mirroring effect, which can be considered as a corollary to the self-other tensions, may well be appreciated by project owners as a stimulus for trying out new behaviors that could support innovation. It could also help people in the organization accept the tension between conformity and creativity, which we will address below.

In the post-experience responses the three groups of participants appear to perceive the tensions between self and other in terms of the differences between the world of the arts and the world of organizations - at least in the way those two worlds tend to be represented (Tables A2, A3 and A4). The artists report having been confronted with "the real world," "concrete challenges," or "real problems"; employees say they have become more aware of different identities and they contrast "the fixed world of the firm" with the "sensitive world" of artists. Both the internal and the external participants report that their way of seeing each other has changed as a result of the encounter. For example:

"I never thought that an artist could bring something practical or systematic to a business task. I always associated them with artistic, creative, advertising activities. ... But now I see that indeed they can!" (POST-Employees).

It is this greater openness to the other that permitted the participants to engage with and accept the "external perspective" that they expected to benefit from at the outset. After the interventions the participants show a greater ability to change and to adapt their practices in their professional contexts (Tables A2, A3 and A4).

"I believe that the tension that is generated between the artists and the firm obliges us to rethink and establish the role of the artist in a process of co-creation. I think that the artist is obliged to change the role he occupies as a result of the relationship that develops, he has to reposition himself in order to help the project advance." (POST-Artists).

"It helped me to get out of my fixed perspective of the business world. Now I intend to do something similar before taking on each new challenge.... And it makes me rethink how I address conflicts that arise from day to day." (POST-Employees)

Engaging during the artistic intervention with the different points of views between the artists and the members of the organization appear to have created the conditions for starting a "process of self-reflection" that allowed them to deal positively with the identity tensions the process unleashed. Managers (project owners) (Table A4) believe that experiencing the self-other tensions in the interaction between the world of the arts and the world of organizations can help suspend certain routines in the organizational culture and unfetter their train of thought. 
"The energy associated with the change with the artists is significant, seeing that the result is much fresher. In addition, it is not subject to standard ways of thinking, but rather connected to freer aspects" (POST-Project owners)

Overall, and not surprisingly, the project owners have a more global view of the intervention and its impacts for the organization than the employees do. For example, they may reflect on the identity tensions in relation to the organizational culture.

"I believe that [the artist] was the catalyst to get us to work on and talk about our organization's culture and mission. ” (POST-Project owners).

However, the difference between the responses to the experience expressed by employees and project owners is not as significant in this sample as it might be in other samples. The small size of many of the organizations meant that the project owners participated in the interventions so their experience was similar to that of employees, whereas in larger organizations project owners tend to commission but not necessarily participate in the artistic interventions.

In summary, understanding the needs of others, learning from others, trying out new forms of collaborating, and developing external perspectives are four ways that emerge from our data as ways of accepting the tension between self and other.

\section{Tension Between Conformity And Creativity}

The respondents in all three groups perceive artistic interventions in organizations as spaces that "open to new experiences", that allow people to "escape from the routine," to "leave the habitual parameters of work." The artists seem to have a wide range of possibilities in terms of the techniques they can use to "provoke changes, reflections, possibilities" or to "stimulate creativity, develop the uniqueness of the people." They talk about "playing, surprising, exploring, mixing", in order to open up, even shake up, conformity and creativity. In their responses to the preexperience questionnaires all three groups of participants refer primarily to the "techniques", "methods" or "ways of working" to stimulate creativity. The artists are expected to bring these tools of their trade to help the organization break out of its normal work mode; and the artists themselves hope that the encounter between the two worlds will generate methodological innovations for their work.

"It produces a displacement for me, in relation to the place where my work is usually offered and received, and it makes me give a different value and reformulate the instruments I usually use for my work.” (PRE-Artists)

"It offers us a new, really interesting experience, a challenge that activates our creative capacity." (PRE-Artists)

After the intervention the language shifts from a focus on instruments to a relational discourse. The participants characterize the experience as "a space of experimentation" among people in which they could dare "not to repeat formats they already knew would work". The responses of employees and project owners illustrate how much effort is needed in organizations to overcome the tension between the pressure for conformity and the desire for creativity. The participants recognized that they need help in "shifting from assuming that a way of seeing business and the work environment is something given, fixed, to conceiving it as something in which we can work and reflect." (POST-Employees)

Artistic interventions can trigger new ways of thinking and doing things in organizational contexts, including handling problems.

"It is an opportunity and very useful experience to introduce a different way of thinking in organizations about solving problems and dealing with new challenges." (POST-Employees)

They help the participants to break out of habits and routines that employees sometimes describe as "asphyxiating" and in which the employees sometimes feel "imprisoned." When the artists bring in these kinds of techniques the employees might "have fun" and develop their "creative potential" but at a deeper level the intention is to stimulate the employees to "seek to understand themselves" and "question themselves." In their responses to the post-experience questionnaires, the project owners (Table A3) emphasized that beyond learning creativity techniques, they became aware of the importance of enabling the employees express themselves and participate in processes. Becoming more autonomous and developing a more open mind set also stimulates creativity.

"The impact lies in seeing that when we intervened less, and employees participated more, there is more creative autonomy that they can achieve." (POST-Project owners)

"A mental opening, not seeking ideas in the daily affairs." (POST-project owners)

In summary, by intensifying the tensions between conformity and creativity, the artistic interventions help people in the organization to recognize the need to free themselves from the pressures to conform to the habitual codes and frames of reference, and to remove the real or subjective barriers to generating new ideas and ways of doing things. Such "extra-ordinary" experiences can be opportunities to create new routines and behaviors that are more effective at work and that enable creativity to be associated with stability rather than opposed to each other. These pragmatic insights come primarily from the project owners, whose managerial perspective provides them with a broader view on the impacts of artistic interventions than employees might have. It is probably why they accepted to invest time and resources into such an unusual initiative.

Overall, therefore, our findings reveal that there are of course certain differences between the expectations and experiences of artists, employees and project owners in artistic interventions, but there are also significant commonalities across the three types of participants. The analysis of responses provides evidence that they are open to accepting inherent tensions, and to dealing positively in particular with the tensions they experience between conformity and creativity, and between self and other orientation.

\section{Discussion}

Our study of artistic interventions in small and medium-sized Spanish companies explored how artists, managers (project owners) and employees express their thoughts and feelings about this intercultural experience. We found that the three types of 
participants are attracted by the opportunity to interact with people whose identities have been shaped by different cultural orientations than their own. Although their intentions in engaging in such interventions do not explicitly include addressing identity tensions, the pre- and post-experience responses show how fertile the situation is for reflecting on these tensions at both the individual and collective levels.

The data analysis revealed tensions between self-and-other, and between conformity-creativity in the participants' responses, and it provided evidence that artistic interventions can help people to accept these tensions in the workplace. Artistic interventions in organizations appear here as a "space of constructive disturbance” (Darsø, 2016, p. 26) in which participants experience possibilities for co-evolution of identities. The analysis of the responses suggests that the stakeholders do not necessarily assess the value of artistic interventions in terms of the results of actions taken. They highlight the value having opened a temporary interspace (Berthoin Antal \& Strauß, 2016, p. 38) of experimentation in the organizational culture; where they were able to artfully and playfully unblock habits, routines, and fixed conceptions of identities in their day-to-day working context (see also Meusburger, 2009, p. 137; Putnam, 2015, p.16). Participating in artistic interventions in organizations contributes to "the social processes implicated in identity formation [which] are complex, recursive, reflexive and constantly under construction" (Ybema et al., 2009, p.301).

The concept of co-evolution emphasizes that identity development in artistic interventions is not one-sided and limited to the members of the organization: the artists, too, engage in a spirit of learning that can also develop their identity. A significant factor enabling this co-evolution is the conviction, which many participants had from the outset, that something good/new/valuable/interesting would emerge from the cultural interaction, even if they had no idea what the process would entail nor what the outcome might look like. This attitude corresponds to the capacity to accept the tensions by differentiating and integrating the conflicting identities and practicing paradoxical thinking.

All three groups of participants found it energizing to discover that the "foreign" practices and interests from the world of the arts, which the artists embodied during the artistic interventions, could enable both personal and organizational development in the world of business. Instead of denying the existence of important differences, responding defensively to the dissonance between them, or privileging one over the other (Putnam, 2015, p. 4), the three types of participants can be said to have experienced a sense of resonance between their worlds that enriched their repertoire of possible ways of seeing and doing things. This discovery might enable managers and employees to expand their identity to include features that they may previously have considered belonging only to the art world, thereby permitting themselves to connect parts of their identity that they had more or less consciously excluded from their work life. For the artists, the discovery of how their ideas and approaches to work can resonate in an organization also opens the field within which they define themselves. In other words, artistic interventions enable all three groups of participants to use paradoxical thinking to work with identity tensions.

This study also contributes to understanding paradoxical thinking (Westenholz, 1993; Putnam, 2015) by illustrating how the participants were able to combine multiple dimensions of identity. Some respondents expressed realistic concerns about the effort the intervention would require, but overall all three groups shared a) curiosity and confidence that the experience would be positive, b) a sense that the intervention could be playful, and c) a willingness to make the effort to engage across the cultural divide. The groundwork for a state of openness was present but needed to be activated together in the spirit of co-evolution between all participants. Our study highlights that the acceptance of identity tension between self and other that Smith and Lewis (2011) identified requires establishing a better relation with the other and a better understanding of the

\begin{tabular}{|c|c|c|}
\hline Concepts from the literature & \multicolumn{2}{|c|}{ Synergies highlighted from our data } \\
\hline \multirow[t]{2}{*}{$\begin{array}{l}\text { Awareness and acceptance of tensions } \\
\text { through paradoxical thinking } \\
\text { (Gotsi et al., 2010; Smith \& Lewis, } 2011 \text {; } \\
\text { Hahn et al., 2014) }\end{array}$} & Artists & $\begin{array}{l}\text { - concerns about usefulness } \\
\text { - concerns about unrealistic expectations } \\
\text { - willingness to develop a common language } \\
\text { - willingness to find ways of playing together } \\
\text { - confidence that the experience would be positive }\end{array}$ \\
\hline & $\begin{array}{l}\text { Employees and } \\
\text { projects owners }\end{array}$ & $\begin{array}{l}\text { - concerns about making the ideas of the artists viable } \\
\text { - concerns about finding time } \\
\text { - willingness to create an excellent connection, communication } \\
\text { - confidence that the experience would be positive }\end{array}$ \\
\hline $\begin{array}{l}\text { Combining self and other } \\
\text { (Smith \& Lewis, } 2011 \text {; Zwang et al., 2015) }\end{array}$ & \multicolumn{2}{|c|}{$\begin{array}{l}\text { - a better understanding of the needs of the other } \\
\text { - engaging with the other's perspective } \\
\text { - learning from others } \\
\text { - trying out new ways of collaborating }\end{array}$} \\
\hline $\begin{array}{l}\text { Combining conformity and creativity } \\
\text { (Smith \& Lewis, } 2011 \text {; Clegg et al., 2002) }\end{array}$ & \multicolumn{2}{|c|}{$\begin{array}{l}\text { - distrust of purely technical or instrumental innovations } \\
\text { - new ways of seeing things } \\
\text { - new ways of doing things }\end{array}$} \\
\hline
\end{tabular}


needs of the other, as well as a capacity to break out of habitual ways of seeing and doing things by engaging with the other's perspective. Furthermore, our study shows that accepting the tension between conformity and creativity, which is also referred to as uniformity/flexibility or control/autonomy (Zhang et al., 2015) depends less on instruments or techniques than on whether people feel free to try out new ways of seeing and doing things in their context.

Artistic interventions in organizations appear to have the capacity for unleashing a virtuous circle favoring the acceptance of tensions, rather than defensiveness. This orientation does not stem from a simple discovery of the advantages of relating to others or of engaging in creative processes, but rather draws its strength from a double move: awareness that relating to others nourishes self-realization, and awareness that creativity can favor stability and conformity. It is therefore not just the capacity to move between one role and the other, or of recognizing the existence of one identity or another; it is also about creating the synergies that are possible between aspects that initially appear to be in opposition to one another. The synergies that can be achieved by accepting the tensions with paradoxical thinking are summarized in Table 1.

\section{Conclusion and Next Steps}

Extending studies on paradoxical thinking and identity development (e.g., Gotsi et al., 2010; Smith \& Lewis, 2011) we have shown how artistic interventions help members of the organization to accept identity tensions at work, in particular between self-and-other, and conformity-creativity. The experience stirs up the tensions in a kind of intercultural encounter between the world of the arts and the world of organizations, and stimulates paradoxical thinking to accept and work with them individually and collectively. Participants discover that they can expand their frames of reference by working with both dimensions of the identity tensions. They can develop new ways of seeing themselves and others as well as new ways of doing things that extend beyond the temporary interspace of the artistic intervention to affect their daily work practices. In other words, artistic interventions enable the emergence of "more-than" responses to paradoxes and identity tensions at work (Putnam, 2015).

Recognizing that identity is not a simple unitary construct and that individuals develop different facets of their identities in different settings (Billet, 2006; Walsh \& Gordon, 2008; White, 1992), this study shows that by inviting artists to work and interact with people in organizations, managers can support individual and collective processes of identity development. Rather than seeking to regulate the identities of employees to achieve organizational goals (Gotsi et al., 2010, p. 785; see also Alvesson \& Willmott, 2002; Kunda, 1992), engaging with artists permits managers to learn to help themselves and others to accept and work constructively with identity tensions that are inherent in complex contexts in which innovation and adaptability are prized.

The limitations of this study are that the post-experience responses were collected a few weeks after the experience, which is still a relatively short time frame for assessing whether the effects on identity tensions and the practice of paradoxical thinking are sustainable. It would be interesting to explore the effects over time of artistic intervention experiences on identities of the participants. There is of course the risk that after a while employees and managers may let go of paradoxical thinking and resort to treating the poles of the tension in isolation. They would then either repress one (for example the artist identity) entirely or swing back and forth between the two identities without being able to combine them. If managers who have experienced artistic interventions and shown the capacity to engage in paradoxical thinking later renounce living with the tensions and yet impose paradoxical demands on employees, they are likely to generate defense mechanisms like cynicism among their staff. For example, after participants have learned to engage in collaborative creation of ideas and products in an artistic intervention, they are likely to be frustrated if their manager reverts to prioritizing the self over the other by using individual assessment measures while claiming to be leading a team effort. Similarly, employees are likely to be frustrated by managers who emphasize conformity over creativity by basing evaluations on established norms while proclaiming the demand for innovation. Splitting the two poles rather than integrating the tensions risks idealizing the image of the creative individual oriented to the "other" while leaving the organizational structure and culture oriented to conformity and the self, thereby impeding the employees' capacity to be truly creative and altruistic. In such a situation, the individual conforms to an artificially homogeneous self, adapting to the imposed uniformity that deprives him or her of creativity and attention to and from others.

Managers can avoid this trap by treating the various dimensions of artistic and business-like identities "as two sides of the same coin, rather than as polarized contradictions" (Gotsi et al., 2010, p. 799). The challenge to management is twofold: to engage in paradoxical thinking rather than acting paradoxically, and to use paradoxical thinking to find ways of transforming managerial practices and organizational processes, rather than (mis-)using artistic interventions to try to impose a transformation on employees.

By creating an organizational structure and culture that permits individuals to express their creativity and their interest in others, managers can provide a work context in which identity tensions can be revealed and accepted. Smith and Lewis (2011) call for setting virtuous cycles in motion, whereby "awareness of tensions triggering a management strategy of acceptance rather than defensiveness. Acceptance entails viewing tensions as an invitation for creativity and opportunity" (Smith \& Lewis, 2011, p. 391). Under what conditions could the experience of artistic interventions, which are "extra-ordinary" and temporary initiatives, nourish such a process over longer periods of time? In other words, how can the paradoxical thinking stimulated by and practiced during an artistic intervention be sustained such that managers and employees can develop organizational cultures in which identity tensions are generative and healthy? Longitudinal research with bold managers (Zambrell, 2016, p. 185), employees, and artists who are willing to experiment with identity tensions at the individual and organizational level and to reflect with researchers about the effects of those experiences with various art forms would be needed to answer that question. 
Lastly, this article offers a new way of discussing issues relating to researchers' identity tensions. The process of collecting and analysing qualitative data on innovative initiatives, of listening to the voices of diverse "others" from the world of the arts and the world of business, involves the researchers in movements between self-and-other orientation for which considerable levels of reflexivity are required. Then, preparing a publication on artistic interventions in organizations for a management journal entails engaging in the delicate dance of moving between conformity and creativity orientations. It is a very special dance, in which the authors start by dancing alone, then they are joined by an editor and reviewers, whose identities are unknown and who are moving to different tunes that may or may not resonate with those of the authors. The dance explicitly offers the potential for learning about and improving the content of the article but also implicitly includes the possibility of exercising paradoxical thinking about the aspects of identity in academia.

\section{References}

AdLER, Nancy J. (2002). International Dimensions of Organizational Behavior, 4th edition. Cincinnati, Ohio: South-Western Publishing.

AdLER, Nancy J. (2011). "Leading beautifully: The creative economy and beyond", Journal of Management Inquiry, Vol. 20, N³, p. 208-221.

AdLER, Nancy J. (2015). "Finding beauty in a fractured world: Art inspires leaders-Leaders change the world", Academy of Management Review, Vol. 40, º3, p. 480-494.

Alvesson, Mats; Willmott, Hugh (2002). "Identity regulation as organizational control: Producing the appropriate individual", Journal of Management Studies, Vol. 39, º5, p. 620-644.

BARry, Daved; MeIsiek, Stefan (2010). "Seeing more and seeing differently: sensemaking, mindfulness and the workarts", Organization Studies, Vol. 31, N¹1, p. 1505-1530.

Berthoin Antal, Ariane (2014). "When arts enter organizational spaces: implications for organizational learning”, In P. Meusburger, A. Berthoin Antal, L. Suarsana (eds.), Learning Organizations. Extending the Field, Knowledge and Space, Vol. 6, Dordrecht: Springer, p. 177-221.

Berthoin Antal, Ariane; Nussbaum Bitran, Ilana (2015). Artistic interventions in organizations: Data reports from multi-stakeholder surveys in Spain 2011-2014. Discussion Paper SP III 2015-603, WZB Berlin Social Science Center.

Berthoin Antal, Ariane; Strauss, Anke (2016). "Multistakeholder perspectives on searching for evidence of values-added in artistic interventions in organizations", In U. Johansson, J. Woodilla and A. Berthoin Antal (eds.), Artistic interventions in organizations: Research, theory and practice, London: Routledge, p. 37-60.

BiLlET, Stephen (2006). "Exercising self through working life: Learning, work and identity", In A. Brown, S. Kirpal and F. Raumer (Eds.), Identities at Work, Dordrecht, NL: Springer, p.183-210.

Cameron, Kim; Quinn, Robert (1988). "Organizational paradox and transformation", In R.E. Quinn and K.S. Cameron (Eds.), Paradox and Transformation: Toward a Theory of Change in Organization and Management, Cambridge: Ballinger, p. 12-18.
Clarke, Caroline A.; Brown, Andrew D.; Hailey, Veronica Hope (2009). "Working identities? Antagonistic discursive resources and managerial identity”, Human Relations, Vol. 62, №3, p. 323-352.

Clegg,, Stewart R.; Vieira da Cunha, Joao; Pina e Cunha, Miguel (2002). "Management paradoxes: A relational view", Human Relations, Vol. 55, N5, p. 483-503.

DARs $\varnothing$, Lotte (2004). Artful creation: learning-tales of arts in business, Frederiksberg, Denmark: Samfundslitteratur.

DARs $\emptyset$, Lotte (2016). "Arts-in-Business from 2004 to 2014. From experiments in practice to research and leadership development", In U. Johansson, J. Woodilla \& A. Berthoin Antal (eds.), Artistic interventions in organizations: Research, theory and practice, London: Routledge, p. 18-34.

Dewey, John (2005). Art as Experience, New York: Penguin Group. (Original work published 1934).

Garcia, Primo; Hardy, Cynthia (2007). “Positioning, similarity and difference: narratives of individual and organisational identities in an Australian university", Scandinavian Journal of Management, Vol. 23, N4, p. 363-83.

Gioia, D.A.; Corley, K.G.; Hamilton, A.L. (2013). "Seeking qualitative rigor in inductive research", Organizational Research Methods, Vol. 16, Nº1, p. 15-31.

Gotsi, Manto; Andriopoulos, Constantine; Lewis, Marianne; Ingram, Amy (2010). "Managing creatives: Paradoxical approaches to identity regulation", Human Relations, Vol. 63, $\mathrm{N}^{\circ} 6$, p. 781-805.

Gulati, R.; Sytch, M.; Tatarynowicz, A. (2012). "The rise and fall of small worlds: exploring the dynamics of social structure", Organization Science, Vol. 23, p. 449-471.

Hahn, Tobias; Preuss, Lutz; Pinkse, Jonatan; Figge, Frank (2014). "Cognitive frames in corporate sustainability: managerial sensemaking with paradoxical and business case frames", Academy of Management Review, Vol. 39, N²4, p. 463-487.

Hatch, Mary Jo; Schultz, Majken (1997). "Relations between organizational culture, identity and image", European Journal of Marketing, Vol. 31, N ${ }^{\circ} 5-6$, p. 356-65

Kunda, Gideon (1992). Engineering Culture: Control and Commitment in a High-tech Corporation, Philadelphia, PA: Temple University Press.

Kenny, Kate; Whittle, Andrea; Willmott, Hugh (2011). Understanding Identity and Organizations, London: SAGE Publications.

LeE, Pei-Wen (2006). "Bridging cultures: Understanding the construction of relational identity in intercultural friendship", Journal of Intercultural Communication Research, Vol. 35, $\mathrm{N}^{\circ} 1$, p. 3-22.

LEWIS, Marianne, (2000). "Exploring paradox: Toward a more comprehensive guide", Academy of Management Review, Vol. 25 p.760-776.

Lewis, Marianne; Andriopoulos, Constantine; Smith, Wendy (2014). "Paradoxical leadership to enable strategic agility", California Management Review, Vol. 56, N³, p. 58-77.

LüsCHER, Lotte; LEwIS, Marianne (2008). “Organizational change and managerial sensemaking: Working through paradox", Academy of Management Journal, Vol. 51, N², p.221-240. 
Maguire, Steve; Hardy, Cynthia (2005). "Identity and collaborative strategy in the case of Canadian HIV/AIDS treatment", Strategic Organization, Vol. 3, Nº, p.11-45.

Massey, Doreen (2004). “Geographies of responsibility”, Geografiska Annaler. Series B. Human Geography. Special issue: The political challenge of relational space, Vol. 86, $\mathrm{N}^{\circ} 1$, p. 5-18.

McNiff, Shaun (1998). Trust the process. An artist's guide to letting go, Boston: Shambhala.

Meisenbach, Rebecca J. (2008). "Working with tensions. Materiality, discourse and (Dis)empowerment in occupational identity negotiation among higher education fund-raisers", Management Communication Quarterly, Vol. 22, №2, p. 258-287.

Meisiek, Stefan; Hatch, Mary J. (2008). “This is work, this is play: Artful interventions and identity dynamics", In D. Barry and H. Hansen (Eds.), The Sage Handbook of New Approaches in Management and Organizations, London: Sage, p. 412-423.

Meusburger, Peter (2009). "Milieus of creativity. The role of places, environments and spatial contexts", In P. Meusburger, J. Funke, E. Wunder (eds.), Milieus of Creativity. An Interdisciplinary Approach to spatiality of Creativity, Knowledge and Space Vol. 2, Dordrecht: Springer, p. 97-153.

Miles, Matthew B.; Huberman, A.Michael (1994). Qualitative Data Analysis, $2^{\text {nd }}$ ed. Thousand Oaks, CA: Sage.

Pache, Anne-Claire; SAntos, Filipe (2013). "Embedded in hybrid contexts: How individuals in organizations respond to competing institutional logics", Institutional Logics in Action, Part B. Research in the Sociology of Organizations, Vol. 39B, p. 3-35.

Poole, Marshall Scott; Van de Ven, Andrew (1989). "Using paradox to build management and organization theories", Academy of Management Review, Vol. 14, N²4, p. 562-578.

Putnam, Linda (2015). “Moving beyond 'both-and' approaches: Alternative strategies for managing paradoxical tensions", Paper presented at the 31st Colloquium of the European Group on Organization Studies, Athens, Greece, July -5, 2015.

Reynaud, Jean-Daniel (1997). Les règles sociales du jeu. L'action collective et la regulation sociale. [The rules of the game. Collective action and social regulation], Paris: Colin.

Schein, Edgar H. (2001). “The role of art and the artist”, Reflections, Vol. 2, Nº, p. 81-83.
Simonton, Dean Keith (2000). "Creativity: Cognitive, personal, developmental, and social aspects”, American Psychologist, Vol. 55, $\mathrm{N}^{\circ} 1$, p.151-158.

Smith, Wendy; Lewis, Marianne (2011). “Toward a theory of paradox: a dynamic equilibrium model of organizing", Academy of Management Review, Vol. 36, N², p. 381-403.

Smith, Wendy; Tushmann, Michael (2005). "Managing strategic contradictions: A top management model for managing innovation streams", Organization Science, Vol. 16, $\mathrm{N}^{\circ} 5$, p. 522-536.

STrauss, Anke (2009). "Context is half the work: an intercultural perspective on arts and business research", Conference Paper presented at SCOS, Copenhagen 8-11 July 2009.

Sussman, Nan M. (2000). "The dynamic nature of cultural identity throughout cultural transitions: Why home is not so sweet", Personality and Social Psychology Review, Vol. 4, N4, p. 355-373.

VAN DER Pol, Hendrik (2011). "Key role of cultural and creative industries in the economy", UNESCO policy paper. http:// www.oecd.org/site/worldforum06/38703999.pdf Accessed July 152015

WALSH, Kate; Gordon, Judith R. (2008). “Creating an individual work identity”, Human Resource Management Review, Vol. 18, $\mathrm{N}^{\circ} 1$ p. 46-61.

Westenholz, Ann (1993). "Paradoxical thinking and change in the frames of reference", Organization Studies, Vol. 14, No 1 , p. 37-58.

White, Harrison C. (1992). Identity and Control. A Structural Theory of Social Action. Princeton, NJ: Princeton University Press.

Ybema, Sierk; Keenoy, Tom; Oswick, Cliff; Beverungen, Armin; Ellis, Nick; Sabellis, Ida (2009). "Articulating identities", Human Relations, Vol. 62, №3, p. 299-322.

ZAMBreLl, Katharina (2016). "Managers in artistic interventions and their leadership approach", In U. Johansson, J. Woodilla and A. Berthoin Antal (eds.), Artistic interventions in organizations: Research, theory and practice, London: Routledge, p. $185-203$.

Zhang, Yan; Waldman, David; Han, Yu-Lan; Li, Xiao-Bei (2015). "Paradoxical leader behaviors in people management: antecedents and consequences", Academy of Management Journal, Vol. 58, N², p. 538-566. 


\section{APPENDIX 1 \\ Open questions selected from our pre- and post-experience surveys for this analysis}

PRE-experience questions

POST-experience questions

\section{Artists}

1. What connection do you see between your work and your upcoming collaboration in XXXLab/Conexiones Improbables?

2. What do you hope will happen in the collaboration with employees of the organization?

3. What kind of signals will you look for to let you know whether this interaction is worthwhile or not?

4. What will give you the feeling that the intervention has been valuable for you as an artist?

1. Do you feel that the interaction between the employees an you as an artista/your collective had an impact on you? If so, what kind of impact do you feel it had?

2. Can you name an idea, a possibility, a feeling, a discovery or something else that you took from this interaction and that you feel is important for you or for your work?

3. What was the most valuable aspect for you of your participation in XXXLab/Conexiones Improbables?

4. Which support activities from the Conexiones Improbables time do you feel were particularly important (a) during the selection process; (b) during the preparation for entering into the organization?

\section{Employees}

1. What connection do you think there is between the artist and your work?

2. What do you hope will happen in the organization during the collaboration with the artist?

1. What significance for your work did the project with the artist have? Please explain your response.

2. Do you think that the interaction between the employees and the artist(s) had an impact on you? If yes, please indicate what kind of effect.

3. Can you describe an idea, possibility, feeling, discovery or anything else that you got out of this interaction that yo feel is important for you personally or professionally?

4. Please specify any other benefits that you experienced personally.

\section{Managerial perspective of project owners (managers)}

1. What do you hope will happen during and after the collaboration between employees the artist(s) in the organization?

2. What kind of signals will you look for to let you know whether this interaction is worthwhile or not?
1. Do you think that the interaction between the employees and the artist(s) had an impact (a) on the employees who participated? (b) on you? If yes, please indicate what kind of effect?

2. How relevant do you feel the collaboration with the artist was?

3. In what way do you think that employees benefitted from the interaction with the artists?

4. What kind of benefit do you think they gained?

Note: we also looked at the responses from all three groups of respondents to the question "What concerns do you have about the artistic intervention?" but the majority said they had none so we are not including it in this table. 


\begin{tabular}{|c|c|c|}
\hline \multicolumn{3}{|c|}{$\begin{array}{l}\text { APPENDIX } 2 \\
\text { Identity tensions and evidence of paradoxical thinking: Examples of responses from the ARTISTS }\end{array}$} \\
\hline & PRE-experience Responses (n=88) & POST-exerience Responses ( $\mathrm{n}=83$ ) \\
\hline $\begin{array}{l}\text { Openness } \\
\text { to accepting } \\
\text { the tensions }\end{array}$ & $\begin{array}{l}\text { - I hoped that the initial barriers would be } \\
\text { dismantled little by Little as we got to know } \\
\text { each other better and they would become } \\
\text { engaged in the project } \\
\text { - I hope that we will enrich each other, that we } \\
\text { can enter into the game of the other by bringing } \\
\text { in what we have. } \\
\text { - We would like to see good lines of dialogue } \\
\text { becoming established during the collaboration } \\
\text { with the members of the organization, to } \\
\text { achieve an understanding of the whole } \\
\text { problematic and a good disposition for } \\
\text { launching into the abyss of the unknown. }\end{array}$ & $\begin{array}{l}\text { - [The intermediary] helped us a lot to prepare the } \\
\text { interviews, they facilitated this process exactly as } \\
\text { inter-mediaries half way between the artists (us) and } \\
\text { the companies. } \\
\text { - Initially I had the impression that they were really } \\
\text { willing to open themselves and try out some things } \\
\text { that they had not done before, but it seems that some } \\
\text { "barriers" existed. Now I have the feeling that they are } \\
\text { going to pursue with great conviction the proposal we } \\
\text { put in motion despite not knowing whether it can be } \\
\text { realized completely. }\end{array}$ \\
\hline $\begin{array}{l}\text { Tensions between } \\
\text { self and other }\end{array}$ & $\begin{array}{l}\text { - We believed that we can learn a lot from this } \\
\text { experience of working with small companies that } \\
\text { are usually far from the world of the arts } \\
\text { - My intuition tells me that talking with an } \\
\text { employee at his level in the daily work situation } \\
\text { will generate an optimal level of empathy to } \\
\text { understand what they hope and wish from the } \\
\text { internal communication of their Company. It is } \\
\text { about building a bridge between two worlds, } \\
\text { between two different-and sometimes } \\
\text { opposed-- perspectives. } \\
\text { For my work any experience that generates a } \\
\text { relationship and interaction (whether it works } \\
\text { out or not) with people in different contexts from } \\
\text { my habitual one is enriching and valuable. }\end{array}$ & $\begin{array}{l}\text { - It was enriching to leave the reality of art and share a } \\
\text { new reality, to understand the daily situation faced by } \\
\text { the company. It offered me new ways of seeing things. } \\
\text { - It was a difficult experience which produced } \\
\text { contradictions for me, about my capabilities, my } \\
\text { position, instruments and tendencies in a situation of } \\
\text { this kind. } \\
\text { - Approaching real problems that are really really latent } \\
\ldots \text { required me to get involved in the context of the } \\
\text { organization in a way that I have never had to do in other } \\
\text { projects in other contexts. } \\
\text { - It helped us show that any connection between } \\
\text { "different others" is posible and that from there new } \\
\text { and stimulating things can emerge. }\end{array}$ \\
\hline $\begin{array}{l}\text { Tensions between } \\
\text { conformity } \\
\text { and creativity }\end{array}$ & $\begin{array}{l}\text { - Creating favorable conditions for creativity, } \\
\text { dialogue and the construction of a project that } \\
\text { will motivate us together, for the same or for } \\
\text { different reasons. } \\
\text { - To change the perspectives of both parties a } \\
\text { bit: for me to work from different perspectives, } \\
\text { and to offer the others also new ways of seeing } \\
\text { things, new lenses. } \\
\text { - I hope that we can reinvent ourselves mutually. } \\
\text { That they give us ways of seeing things that allow } \\
\text { us to reconfigure our ideas and at the same time } \\
\text { that the ideas we have can be useful for their } \\
\text { interests. }\end{array}$ & $\begin{array}{l}\text { - It strengthened my self-confidence and it was } \\
\text { empowering because I know that they valued the } \\
\text { initiative as very positive; and for me it was a task that } \\
\text { did not require titanic levels of effort nor a punishing } \\
\text { road; rather I felt good doing it and it became a space } \\
\text { of experimentation (not of repeating a format I already } \\
\text { knew and that I was sure would work). } \\
\text { - It presupposees an exercise with artistic instruments } \\
\text { through a different process that gets us to refl ect } \\
\text { and discover new possibilities with the instruments } \\
\text { themselves. } \\
\text { The richness of exchanging views and the variety of } \\
\text { ways of addressing similar problems from a multitude } \\
\text { of different foci. }\end{array}$ \\
\hline
\end{tabular}




\begin{tabular}{|c|c|c|}
\hline \multicolumn{3}{|c|}{$\begin{array}{l}\text { APPENDIX } 3 \\
\text { Identity tensions and evidence of paradoxical thinking: Examples of responses from the EMPLOYEES }\end{array}$} \\
\hline & PRE-experience Responses ( $n=110$ ) & POST-experience Responses ( $\mathrm{n}=68$ ) \\
\hline $\begin{array}{l}\text { Openness } \\
\text { to accepting } \\
\text { the tensions }\end{array}$ & $\begin{array}{l}\text { - I cannot conceive of this connection without two } \\
\text { important factors which will get both parties to } \\
\text { create strong bonds: First the knowledge that } \\
\text { both parties have of the other... And second } \\
\text { that there is a chemistry between both parties, } \\
\text { trust and understanding. }\end{array}$ & $\begin{array}{l}\text { - I think that if the majority of the members of the } \\
\text { organization had the opportunity to know the projects } \\
\text { more directly, the experiences, and doubts etc of other } \\
\text { organizations, their attitude would be more open and } \\
\text { positive. I think that this would also help to dissipate } \\
\text { the negative uncertainty and the lack of trust. }\end{array}$ \\
\hline $\begin{array}{l}\text { Tensions between } \\
\text { self and other }\end{array}$ & $\begin{array}{l}\text { - We are entering into a big bet with this project. If } \\
\text { we all pull together, getting to know each other, } \\
\text { sharing and analysing bit by bit, we can gain new } \\
\text { perspectives or solutions that we cannot currently } \\
\text { achieve. I think it is very positive that someone } \\
\text { external enters fully into our working group and } \\
\text { helps us to see things in a different way. } \\
\text { - I hope there will be a connection between the } \\
\text { artist and the company, which will help us } \\
\text { perform our work better and will bring us new } \\
\text { ideas. In some way, that it will open our minds a } \\
\text { bit more. }\end{array}$ & $\begin{array}{l}\text { - It had a positive impact on the feeling that we almost } \\
\text { always see, work or analyse things in the same way and } \\
\text { that a new perspective like that of the artist brings a lot. } \\
\text { - Interacting with people who have a very different profile } \\
\text { from the usual one and who have fresh ideas that we } \\
\text { lack because of the daily monotony. } \\
\text { - You re-consider many things from a different } \\
\text { perspective. You get to know other professionals who } \\
\text { have different profiles from your team and you expand } \\
\text { your perspective of the world of innovation. It is a huge } \\
\text { learing process. You make an effort, you oblige yourself } \\
\text { to open new ways of working and doing things. }\end{array}$ \\
\hline $\begin{array}{l}\text { Tensions between } \\
\text { conformity } \\
\text { and creativity }\end{array}$ & $\begin{array}{l}\text { - I imagine that it can open my eyes and help } \\
\text { me to see things from a different perspective; } \\
\text { I imagine that it can help me expand my } \\
\text { potential and potentialities. I imagine that it } \\
\text { can complement my work, which is sometimes } \\
\text { excessively technical, with the creativity that is } \\
\text { characteristic of the arts. } \\
\text { - I hope for new ideas, risky proposals, somewhat } \\
\text { crazy, creativity and changes. } \\
\text { - I hope that it will break certain clichés, ... I hope } \\
\text { that the project will bring us new instruments to } \\
\text { improve our team work. That it will change some } \\
\text { of our methods, some of our established ways } \\
\text { of doing things, we will expand our perspectives } \\
\text { from our daily approach and make changes in } \\
\text { our way of innovating. }\end{array}$ & $\begin{array}{l}\text { - We have experienced new ways of working and of } \\
\text { innovating. } \\
\text { - Applying creativity to real problems in the organization. } \\
\text { - It entailed interrupting the daily stress to dedicate } \\
\text { ourselves to thinking. See that things can be done in } \\
\text { another way. That with fun methodology one can do } \\
\text { - Therious things. } \\
\text { - } \text { - Breative and innovative way of seeing things. } \\
\text { informal as a useful instrument, the thousand and one } \\
\text { possibilities that things have, that nothing and everything } \\
\text { has value, depending on the destiny it is given. }\end{array}$ \\
\hline
\end{tabular}




\begin{tabular}{|c|c|c|}
\hline \multicolumn{3}{|c|}{$\begin{array}{c}\text { APPENDIX } 4 \\
\text { Identity tensions and evidence of paradoxical thinking: Examples of responses } \\
\text { from the managerial perspective of PROJECT OWNERS (MANAGERS) }\end{array}$} \\
\hline & Responses PRE (n=73) & Responses POST ( $n=59)$ \\
\hline $\begin{array}{l}\text { Openness } \\
\text { to accepting } \\
\text { the tensions }\end{array}$ & $\begin{array}{l}\text { - [sign of a successful interaction]: the quality } \\
\text { of the relationship, the quality of the process } \\
\text { of thinking together, the learning in whichever } \\
\text { possible manner, the options that emerge as } \\
\text { the fruit of this relationship and collaboration, } \\
\text { and the concrete result of the working } \\
\text { sessions. } \\
\text { - I hope to open the mind... And I hope for an } \\
\text { ambitious and challenging project. }\end{array}$ & $\begin{array}{l}\text { - The mutual understanding resulted in developing a } \\
\text { common language and a common orientation, which } \\
\text { stimulated our artists and was noticed in the level and } \\
\text { quality of their contributions. } \\
\text { - From the beginning I tried to break the idea of } \\
\text { assistant so that we could both create from the same } \\
\text { place. This is how I got to integrate the artist's gaze } \\
\text { and to see and propose things together. } \\
\text { - Because the artists understood our work and got } \\
\text { involved in it quickly. } \\
\text { - The extent of the artist's capacity to search and absorb } \\
\text { the knowledge. }\end{array}$ \\
\hline $\begin{array}{l}\text { Tensions between } \\
\text { self and other }\end{array}$ & $\begin{array}{l}\text { - At first, getting another perspective from outside } \\
\text { and open ourselves for new ideas and we hope } \\
\text { for future results. } \\
\text { - [Hope] that we will learn to see ourselves from } \\
\text { another perspective, as much our strengths as } \\
\text { our weaknesses. }\end{array}$ & $\begin{array}{l}\text { - The artists help employees to see the same projects in } \\
\text { - new way, "from out of the box" [English original]. } \\
\text { - Because artists never stop surprising you with their } \\
\text { different way of seeing reality. }\end{array}$ \\
\hline $\begin{array}{l}\text { Tensions between } \\
\text { conformity and } \\
\text { creativity }\end{array}$ & $\begin{array}{l}\text { - [Hope] that they push us to think of new methods } \\
\text { of working. } \\
\text { - Surprises, innovations, creativity, new models } \\
\text { for perceiving, showing the product, definitely a } \\
\text { great motivation for interaction among ourselves } \\
\text { and with our customers. } \\
\text { - [Hope] that new ideas emerge, contrasting those } \\
\text { that we have, give an impulse for creativity as a } \\
\text { fundamental instrument of communication. }\end{array}$ & $\begin{array}{l}\text { - Employees are more interested in topics relating to } \\
\text { innovation. } \\
\text { - Employees have started to act with more creative } \\
\text { autonomy, improving the space, their relations and } \\
\text { service. } \\
\text { - Incorporation of other methodologies. } \\
\text { - Discovering that there are many people who are in tune } \\
\text { with doing things in a different way (creativity). }\end{array}$ \\
\hline
\end{tabular}

